\section{Investigation of Reflecting Reading Comprehension Strategies on Teaching Environment among Pre-service Classroom Teachers*}

\author{
Mehmet Asıkcana ${ }^{a}$ Gulhiz Pilten ${ }^{b, *}$, Aliya Kuralbayeva
}

\begin{tabular}{ll}
\hline Received: & 07 December 2017 \\
Revised: & 19 December 2017 \\
Accepted: $\quad 21$ December 2017 \\
ISSN: 1307-9298 \\
Copyright @ IEJEE \\
www.iejee.com
\end{tabular}

DOI: $10.26822 /$ iejee.2018438129

\begin{abstract}
The purpose of the study is to define the reading comprehension strategies considered by pre-service classroom teachers to be applicable in the classroom and their practical designs related to these strategies in terms of selecting text appropriate strategy, and full and correct use of the strategies in reading process (pre-reading, during-reading, post-reading, whole reading process) in accordance with the conceptual framework defined in the literature. The study has been conducted as a case study which is one of the qualitative research designs. The sampling group has been composed of 140 undergraduate students. Data collected through interviews, have been analysed with the help of document analysis method. Results indicate that pre-service teachers have used almost half of strategies defined as pre-reading strategies in the literature. Among the used strategies, the most repeated ones are guesses by visuals and stimulating prior knowledge. According to another finding of the study, pre-service teachers used only a few of the during-reading strategies defined in the literature. Finally, pre-service teachers designed post-reading strategies the most, and the strategy variation was accordingly the most for post-reading.
\end{abstract}

Keywords: Reading comprehension strategies, pre-service classroom teachers, activity designs

\section{Introduction}

Attaining automaticity with multiplication facts is both a de Reading comprehension is a skill that is founded during primary school years and can be developed within process. Teaching skills of reading and making meaning of what is read takes its place in educational programs and teaching process as the most important contribution to making human life meaningful (Akyol, 2011). Since the main purpose of reading is the efficacy of the communication between the ideas and the readers, students need to have skills and strategies required to obtain information from print sources (Collins \& Cheek, 1999). At this point, the concept of "reading strategies" comes into prominence. Haris and Hodges (1995) define reading strategy as a systematic plan used consciously to increase learning performance. Reading strategies can also be defined as a series of problem solving behaviour used to make meaning of the text or cognitive tools that can develop students' academic performance and mental processes that can be chosen consciously when comprehension gets difficult (Barnett, 1988; Piloneita, 2006; Cohen, 1990).

Reading comprehension strategies are classified under different titles in the related literature. One of these classifications was made by Taraban et al. (2004), who took reading strategies in two dimensions as analytical reading and pragmatic reading strategies. Analytical reading strategies involve the use of strategies requiring the readers to evaluate, think how they can use what they obtain from the text later, deduce from the title what they read, make use of their prior knowledge, review, reflect, distinguish, make inferences, re-evaluate their purposes, select the relevant information, guess, make meaning, check the correctness of the guessed information, reveal their strengths during reading, visualize and define the difficulty level of the text. Pragmatic reading strategies can be defined as strategies that help readers to remember what they read more by using activities such as note taking, colouring or underlining important points, taking notes on the margins, highlighting, reading more than once and re-reading.

Another common classification in the literature organizes reading comprehension strategies in the order they are used during reading process and separated under four main headings (Daly et al., 2005; Duke \& Pearson, 2002; Collins \& Cheek, 1999; Susar, 2006; Epçaçan, 2009; Topuzkanamış \& Maltepe, 2010). These are; (1) pre-reading strategies, (2) during-reading strategies, (3) post-reading strategies and (4) strategies used during whole reading process.

Pre-reading strategies are used by readers to prepare themselves for reading. Some of the pre-reading strategies mentioned in the literature are: (1) forming the purpose of reading; (2) helping students with guessing the topic of the text by checking the title, publication date, author and scanning the text and brainstorming with this purpose; (3) Title, Examine, Look, Look, and Setting (TELLS)-preparing story/ concept map; (4) creating/checking pre-teaching vocabulary; (5) using sources such as dictionaries; (6) pre-teaching using concept maps and story maps; (7) carefully selecting the reading material and letting the students select reading texts in accordance with some criteria; (8) reviewing/investigating; (9) stimulating prior knowledge; (10) writing questions; (11) guessing, forming hypotheses; (12) making word pools; (13) making schemas; (14) creating KWLWH chart (Know-Want to Know-Learned-What else to learn-How).

The second dimension in classification referring to the order of strategy is during reading strategies. The main objective of during-reading strategies is to focus on the target defined in pre-reading. Some of the during-reading strategies mentioned in the literature are: (1) providing fluent and

\footnotetext{
A certain portion of this study has been presented in 15th International Primary Teacher Education Symposium in 11-14 May 2016, Mugla-Turkey Necmettin Erbakan University, A. Kelesoglu Faculty of Education, Konya, Turkey. E-mail: masikcan@konya.edu.tr

**,b Corresponding Author: Gulhiz Pilten, Khoja Akhmet Yassawi International Kazakh-Turkish University, Faculty of Human Sciences, Turkistan, Kazakhstan. E-mail: gulhizp@yahoo.com.tr

cAliya Kuralbayeva, Khoja Akhmet Yassawi International Kazakh-Turkish University, Faculty of Human Sciences, Turkistan,Kazakhstan.

E-mail: kural-aliya84@mail.ru

(c) 2017 Published by T\& K Academic. This is an open access article under the CC BY- NC- ND license. (https://creativecommons.org/licenses/by/4.0/)
} 
absorbing reading; (2) taking story map into consideration for narrative texts; (3) using drafts and study guide for informative texts; (4) strategic note taking for informative texts; (5) using timelines and flow diagrams for informative texts; (6) making complicated plans, tables; (7) using visuals for narrative texts; (8) checking comprehension; (9) defining words; (10) establishing relationships; (11) visualising; (12) answering questions and forming new questions; (13) focusing on the target.

The third dimension in the classification is post-reading strategies. The main purpose of post-reading strategies is strengthening and synthesizing the relations between pre-reading knowledge and post-reading knowledge. Some of the post-reading strategies mentioned in the literature are: (1) summarizing for all kinds of texts; (2) using the question-answer relations; (3) summarizing; (4) answering questions; (5) synthesizing; (6) expressing the text with visual elements; (7) evaluation; (8) analysing; (9) drawing; using graphic organizers; (10) reflective thinking; (11) checking the correctness of the pre-reading guesses; (12) finding the main idea; (13) discussing the text with others.

The fourth dimension of classification involves the strategies that should be used during whole reading process. These are: (1) strategic note-taking; (2) SQ4R: Scan, Question, Read, Reflect, Recite, Review; (3) Multi-pass; (4) Reciprocal Teaching; (5) KWL: Know-Want to Know-Learned; (5) Collaborative Strategic Reading; (6) Concept Map And Graphic Organizers; (7) Coop-Dis-Q: Cooperative Learning-Discussion-Questioning; (8) POSSE (Predict-Organize-Search-Summarize-Evaluate); (9) PQRS (Preview-Question-Read-Summarize); (10) Questions/Asking questions.

Reading strategies are activities that can develop individuals both in terms of knowledge and cognitively as they are defined as cognitive strategies used when there is a reading comprehension problem. From this perspective, reading strategies can be benefited from not only in reading comprehension but also in other classes (Topuzkanamış \& Maltepe, 2010). The related literature involves many studies on the reading comprehension strategies using levels of teachers, who play an important role in raising strategic readers.

One of these was conducted by Çöğmen (2008), who aimed at defining the reading strategy using frequency of students of faculties of education while reading course texts and studying this in terms of various variables. In the study conducted with 230 pre-service teachers, Meta-Cognitive Reading Strategies Scale (MCRS) involving two dimensions as analytical and pragmatic strategies, developed by Taraban et al. (2004) was used to define reading comprehension strategies used by the participants. Some of the findings of the study are: (1) students' reading comprehension strategies using levels were 'frequently' for both dimensions and the whole of the scale. (2) Frequency of using reading comprehension strategies didn't vary by branches in 'analytical strategies' dimension, while they did in 'pragmatic strategies' dimension. Accordingly, Pre-Service Turkish Language Teachers reported using pragmatic strategies less.

Similarly, Karasakaloğlu (2012) aimed at investigating whether pre-service classroom teachers' levels of pragmatic and analytical reading strategies varied significantly by attitude, motivation, time-use, anxiety, concentration, processing knowledge, choosing main ideas, study helpers, self-testing and testing strategies, which are sub-dimensions of learning and studying strategies, being upper or lower level. According to the findings, pre-service classroom teachers used both analytical and pragmatic strategies 'frequently'.

Karatay (2007) studied pre-service Turkish language teachers' reading comprehension achievement and levels of using reading strategies. According to the findings, pre-service Turkish language teachers' reading comprehension achievement varied significantly by text types and their levels of using reading strategies were generally medium level.

Çöğmen and Saracaoğlu (2009) also conducted a similar study on pre-service teachers and reported that their participants' levels of using reading comprehension strategies were at 'frequently' level. The related literature involves studies on defining the types of reading comprehension strategies used by pre-service teachers, besides their using reading comprehension strategies frequency. Tabaran et al. (2004) tried to define the reading comprehension strategies used by pre-service classroom teachers, who thought analytically and holistically in problem solving and they reported the following findings. Pre-service classroom teachers mostly preferred using analytical thinking styles, used analytical and pragmatic reading strategies frequently and pre-service teachers' thinking styles didn't vary significantly by gender, grade and grade point average (GPA). They also reported that pre-service teachers' analytical reading strategies varied significantly by gender and GPA but not by grade.

Supancic (1995), who wrote his master's thesis on teachers' use of reading strategies and their achievement at vocational high schools, reported that teachers used the strategies. The total of 355 vocational high school teacher participated in the study and the questionnaire form developed by the researcher was sent to each participant by e-mail. $93 \%$ of the vocational high school teachers reported using reading comprehension strategies in their classes. This case didn't vary significantly by such variable as gender, seniority and number of students enrolled to the school. The participants' answers on the type of activity they used were as: $62 \%$ pre-reading activities, $68 \%$ vocabulary based activities, $45 \%$ supervised reading activities, $75 \%$ note-taking activities and $48 \%$ graphic organizers.

Ince (2012) tried to define classroom teachers' levels of using reading comprehension strategies in Turkish classes. According to the findings, the most frequently used pre-reading strategy was stimulating pre-existing knowledge while the least used was creating expectations; most used during-reading strategy was answering questions and asking new questions and the least used was taking notes on the margins; most used post-reading strategy was answering questions while the least used was strategic note taking.

A general evaluation of the related studies indicates that pre-service teachers use reading comprehension strategies frequently (Çöğmen, 2008; Karasakaloğlu, 2012; Karatay, 2007; Çöğmen \& Saracaoğlu, 2009). Additionally, pre-service teachers use both analytical and pragmatic strategies (Supancic, 1995; Karasakaloğlu, 2012; Çöğmen, 2008; Ince, 2012). Most of the studies on the types of reading comprehension strategies used by pre-service teachers preferred the classification as analytical and pragmatic. Additionally, similar studies in the related literature used surveys for data collection and obtained teachers' or pre-service teachers' opinions through this technique. The present study aims at defining types reading comprehension strategies used by pre-service teachers on the basis of classification of the order of use in terms of the participants' departments at their faculties. At this point, we believe that the present study will contribute to the literature 
with a different perspective. Additionally, we believe that pre-service teachers' applying their reflecting of reading comprehension strategies on teaching environment will provide more detailed and reliable data compared to surveys, which many of the similar studies in the related literature utilized. Accordingly, the purpose of the present study is defining the reading comprehension strategies considered applicable in the classroom by pre-service classroom teachers and their practical designs related to these strategies; in terms of selecting text appropriate strategy, and full and correct use of the strategies in reading process (pre-reading, during-reading, post-reading, whole reading process) within the conceptual framework defined in the literature.

The problem statement of the study is "Which reading comprehension strategies do pre-service classroom teachers reflect on teaching environment?" Answers to following questions are sought accordingly:

1. For which reading processes do pre-service classroom teachers prefer to use reading comprehension strategies? 2. Can pre-service classroom teachers reflect reading comprehension strategies on educational environment fully and correctly?

3. Which pre-reading comprehension strategies do pre-service classroom teachers prefer to use?

4. Which during-reading comprehension strategies do pre-service classroom teachers prefer to use?

5. Which post-reading comprehension strategies do pre-service classroom teachers prefer to use?

6. Which whole-reading process comprehension strategies do pre-service classroom teachers prefer to use?

\section{Method}

\section{Research design}

The present study on defining which reading comprehension strategies will pre-service classroom teachers use in reading environments is modelled as an illustrative case study. Case study can be defined as a research method that investigates phenomena in their own environment, with no distinct borders between the phenomena and their environment, based on "how" and "why" question, and enables the researchers to investigate in detail any phenomenon or event they cannot control (Yıldırım \& Şimşek, 2005). What distinguishes case study from other methods is that it is based on 'how' and 'why', enables researchers to be included in a phenomenon or event they cannot control and investigate it in detail (Ekiz, 2009). The reasons for using this model in the present study are, that the reading comprehension strategies pre-service classroom teachers will use are accepted as a case with no distinct borders and that cannot be controlled by the researchers; and that this model enables researchers get involved in this case, investigate it in detail and find answers to "why-how" questions.

The present study is designed in accordance with "holistic single case study", which is one of the case study designs. Holistic single case studies involve one single analysis unit. It is used to confirm or reject a well-formulated hypothesis, to study unique or extreme cases, or for cases never studies or revealed before (Yıldırım \& Şimşek, 2005). The single case studied in the present study is the reading comprehension strategies that pre-service teachers will use in their reading teaching designs they are planning to use. The present study takes pre-service teachers as an analysis unit.

\section{Participants}

The work group of the present study consists of the total of 140 (115 female, 25 male) senior (fourth) year students, who studied at Necmettin Erbakan University, Ahmet Kelesoglu Faculty of Education, Department of Classroom Teaching in the spring semester of 2015-2016 academic year. The sample was formed in accordance with criterion sampling, which is a purposive sampling method. Purposive sampling enables the studying of cases, which are thought to have rich information (Patton, 1997). The main principle of criterion sampling is studying of the all cases meeting a series of pre-determined criteria. The criterion or criteria can be formed by the researchers of they can use a prepared criterion list (Yıldııım \& Şimşek, 2005). The criterion for the selection of the pre-service teachers to participate in the present study was that they were informed of Turkish language teaching technique in various courses (Turkish Teaching, Early Reading and Writing Teaching) and they had practice in these subjects, they had completed their teaching practice course and were last year students, who were ready to graduate.

\section{Data collection tools}

In order to collect data, the participants were provided with a narrative text (Turtle the Pottery Master) from the primary school $4^{\text {th }}$ grade Turkish course book, and they were asked to explain which strategy or strategies they would use to provide the best reading comprehension among primary school $4^{\text {th }}$ graders. Text has been identified by researchers. Then, in order to determine the suitability of the selected text, the opinions of the expert group consisting of three persons have taken. First, the experts are asked to evaluate the text literarily taking into account the student's level of development who will read the text. It has found out that all of the experts have the opinion that literary value of the text presented to them is suitable in terms of (1) containing a processed language and narrative; (2) waking up nice emotions, dreams and pleasures in the person; (3) nurturing human emotions, thoughts and dreams; (4) carrying the social and cultural characteristics of the community it belongs to; (5) putting human at the centre of the text; (6) having the purpose to reveal the goodness; (7) reflecting the characteristics of the societies in present and past; (8) using the life-related words, and the text is literarily appropriate for the 4 th grade students. The selected text consists of 757 words, 42 paragraphs and 78 lines. There are five visuals in the text to support story fiction. The text has been presented to the teacher candidates in five pages along with the visuals, as shown in the course book mentioned above. In terms of the quantitative characteristics mentioned, the text has been also found suitable by the expert group for the $4^{\text {th }}$ grade level. In addition, it has been confirmed by all the expert group that the selected text is also appropriate in terms of the text elements (Stage, Main characters and Supporting characters, the event that started the problem, Problem, Problem solving attempts, Result, Main idea, Response) (Akyol. 1999). The reason for selecting a narrative text or the present study was that narrative texts are designed to reflect many cases of communication, such as indicating a point, entertaining the audience, complaint and creating an environment of discussion especially among primary school children, who find these interesting since they encounter with these frequently, and also that they are considered as an important tool of thinking, explaining, comprehension and reminder (Akyol, 2011; Graesser, Golding, \& Long, 1991). 
After selecting an appropriate text, the course design development studies of the teacher candidates have been carried out in four sessions. 43, 41, 36, 40 participants have been found in each session respectively. In the sessions, primarily, purpose of research has been explained to the teacher candidates. Then, in terms of the purpose of the research the importance of creating the course designs in all details has been emphasized. Teacher candidates' questions have been answered and the sessions have been started. Sessions have been held at classrooms in the university building where prospective teachers always study. During the sessions, at least, two of the researchers have been provided to be observers. Pre-service teachers were asked to develop a lesson design, in which they could use the reading comprehension strategy they find appropriate for the text they were provided with. They were also provided with the "Reading Activity Form" presented in the Appendix to use while they develop their lesson design. No time limitation was place on the pre-service teacher for the designing process, yet they were observed to complete their activity design within an average of 30 minutes.

\section{Data analysis}

During the data analysis process of the present study, document analysis was conducted on the lesson designs developed by the pre-service teachers, in order to evaluate the appropriateness of the strategies with the selected text; whether their design reflected the strategies selected by them and the applicability of the selected strategy during reading process. Some of the most common data collection methods used in case studies are interview, observation and document analysis (Yıldırım \& Şimşek, 2005). Document analysis involves the analysis of the written materials including information about the phenomenon or phenomena under study. Document analysis can be the single data collection method for qualitative studies, and it can also be combined with other methods of data collection. To provide the validity and reliability of the study, four elements were taken into consideration (Yin, 2003). These are presented in Table 1.

Table 1. Validity and Reliability Studies

\begin{tabular}{|c|c|c|}
\hline Test & Case study tactic & $\begin{array}{l}\text { Relevant phase } \\
\text { of research }\end{array}$ \\
\hline $\begin{array}{l}\text { Construct } \\
\text { validity }\end{array}$ & $\begin{array}{c}\text { - Establish chain } \\
\text { of events } \\
\text { - Have key inform- } \\
\text { ants review draft } \\
\text { case study report }\end{array}$ & $\begin{array}{l}\text { - Data collection } \\
\text { Reporting }\end{array}$ \\
\hline $\begin{array}{l}\text { Internal va- } \\
\text { lidity }\end{array}$ & $\begin{array}{c}\text { - Do explanation } \\
\text { building }\end{array}$ & - Data analysis \\
\hline $\begin{array}{l}\text { External va- } \\
\text { lidity }\end{array}$ & $\begin{array}{l}\text { - Use theory in } \\
\text { single case studies }\end{array}$ & $\begin{array}{l}\text { - Research } \\
\text { design }\end{array}$ \\
\hline Reliability & $\begin{array}{l}\text { - Use case study } \\
\text { protocol }\end{array}$ & - All phases \\
\hline
\end{tabular}

Source: Yin (2003)

As presented in Table 1, to provide construct validity for the research, first a chain of events was established for the collected data. For this purpose, during the stage of associating the strategies used by the pre-service teachers in the designs they developed with the strategies defined in the literature, the researchers tried to refer to the literature by collecting as many proofs as possible. Pre-service teachers' expressions were also presented in the study with the same purpose. At this stage, pre-service teachers were coded. Such a code as M21M refers to a participant named Mustafa, who is $21^{\text {st }}$ on the list and male. A pre-ser- vice teacher was asked to read the case study report prepared in addition to take her opinion. As presented in Table 1 , we tried to present clearly how the findings were obtained during the data analysis stage and the proofs related to the inferences are presented in a way that others can access for internal validity (Yıldırım \& Şimşek, 2008). For external validity, we tried to explain the research process and what was done during this process in a detailed way. At this context, research model, study group, data collection tool, data collection process, data analysis and interpretation were all defined in a detailed way (Table 1). Finally, for reliability, the steps followed for the present study were explained in detail so other researchers can follow the same steps and reach the same conclusions for further studies. With this purpose, eight major steps to follow for a case study, defined by Yıldırım and Şimşek (2008) were followed: (1) Developing research questions; (2) developing sub-problems of the research; (3) defining the analysis unit; (4) defining the case to study; (5) selection of the individuals to participate in the research; (6) data collection and associating the collected data with sub-problems; (7) data analysis and interpretation; (8) reporting the case study.

\section{Findings}

Evaluation of the reading comprehension strategies used by pre-service classroom teachers in terms of reading processes

First of all, we tried to analyse the place in the reading process of the reading comprehension strategies preferred by pre-service classroom teachers to teach the narrative text they were provided with. Findings obtained related to strategy-process context are presented in Table 2.

Table 2. Reading Processes in Which Reading Strategies were Included

\begin{tabular}{ccrr}
\hline Strategy & Process & $f$ & $\%$ \\
\hline $\begin{array}{c}\text { Designs for the } \\
\text { whole process }\end{array}$ & $\begin{array}{c}\text { Pre-During- } \\
\text { Post-Reading }\end{array}$ & 71 & 50.71 \\
\hline \multirow{2}{*}{$\begin{array}{c}\text { Designs for a } \\
\text { single process }\end{array}$} & Pre-reading & 4 & 2.86 \\
\cline { 2 - 4 } & During-reading & 2 & 1.43 \\
\cline { 2 - 4 } Post-reading & 17 & 12.14 \\
\hline \multirow{2}{*}{$\begin{array}{c}\text { Designs for two } \\
\text { processes }\end{array}$} & $\begin{array}{c}\text { Pre-Post- } \\
\text { Reading }\end{array}$ & 37 & 26.43 \\
\cline { 2 - 4 } & $\begin{array}{c}\text { During- } \\
\text { Post-Reading }\end{array}$ & 9 & 6.43 \\
\hline Total & 140 & 100 \\
\hline
\end{tabular}

As presented in Table 2, almost half of the pre-service teachers $(50.71 \%)$ developed reading comprehension strategies for whole reading process. Additionally, participants whose designs included two processes mostly preferred pre-reading and post-reading strategies (26.43\%). Only a few of these participants (6.43\%) used strategies for during-reading and post-reading processes and didn't develop strategies for pre-reading (Table 2). Additionally, most of the pre-service teachers, who designed for a single process (12.14\%) preferred post-reading strategies. A general evaluation of these findings show that a very small portion of the pre-service teachers developed strategies focused on one process of reading, and they mostly aim at providing reading comprehension for the selected narrative text using strategies in two or three processes of reading. Additionally, pre-service teachers used pre-reading and post-reading comprehension strategies more than during-reading strategies. 
Evaluation of whether pre-service classroom teachers could reflect reading comprehension strategies on the education environment fully and correctly

The second focus of the present study was whether reading comprehension strategies presented in the distribution in Table 2 were used in the processes of reading fully and correctly as defined in the literature. Related findings are presented in Table 3.

Table 3. Whether Strategies are Reflected on Reading Process Fully and Correctly

\begin{tabular}{ccccccccc}
\hline & \multicolumn{7}{c}{ Reflection level } \\
\cline { 2 - 8 } $\begin{array}{c}\text { Process- } \\
\text { Strategy }\end{array}$ & $\begin{array}{c}\text { Completely } \\
\text { Reflects }\end{array}$ & $\begin{array}{c}\text { Pretty } \\
\text { much } \\
\text { reflects }\end{array}$ & $\begin{array}{c}\text { Partially } \\
\text { reflects }\end{array}$ & $\begin{array}{c}\text { Doesn't } \\
\text { reflect }\end{array}$ \\
\cline { 2 - 9 } & $f$ & $\%$ & $f$ & $\%$ & $f$ & $\%$ & $f$ & $\%$ \\
\hline $\begin{array}{c}\text { Pre- } \\
\text { reading } \\
\text { strategies }\end{array}$ & 26 & 15.57 & 43 & 25.75 & 82 & 40.1 & 16 & 9.58 \\
\hline $\begin{array}{c}\text { During- } \\
\text { reading } \\
\text { strategies }\end{array}$ & 21 & 17.65 & 28 & 23.53 & 53 & 44.54 & 17 & 14.28 \\
\hline $\begin{array}{c}\text { Post- } \\
\text { reading } \\
\text { strategies }\end{array}$ & 31 & 17.71 & 45 & 25.71 & 86 & 49.14 & 13 & 7.43 \\
\hline $\begin{array}{c}\text { Whole } \\
\text { reading } \\
\text { process } \\
\text { strategies }\end{array}$ & 1 & 11.11 & 2 & 22.22 & 5 & 55.55 & 1 & 11.11 \\
\hline
\end{tabular}

As presented in Table 3, pre-service teachers could mostly partially reflect the strategies they designed on the all of the reading process parts they targeted at. More clearly, pre-reading strategies developed by $40.1 \%$, during-reading strategies developed by $44.54 \%$, post-reading strategies developed by $49.14 \%$ and whole reading process strategies developed by $55.55 \%$ of the pre-service teachers could be partially reflected on the teaching environment, compared to the definitions of these strategies provided in the literature. Additionally, in terms of pre-service teachers' ability to reflect the strategies on all reading process parts, the least observed case was that pre-ser- vice teachers could select an appropriate strategy for the reading process part yet they couldn't handle those strategies fully and correctly in terms of the literature. This was presented on "doesn't reflect" column in Table 3.

Evaluation of the pre-reading comprehension strategies used by pre-service classroom teachers

Other questions of the present study are related to the definition of the pre-during-post-reading strategies used by pre-service teachers. In this context, findings related to the analyses of pre-reading comprehension strategies used by pre-service teachers are presented in Table 4.

As presented in Table 4, pre-service teachers used only 7 of the 15 pre-reading comprehension strategy presented in the literature, and designed the total of 167 teaching environments for these 7 strategies. The most repeated pre-reading strategy by pre-service teachers was guessing. In the teaching designs planned for this strategy, the most commonly preferred activity was the use of visuals (27.54\%). Other teaching designs for guessing strategy were by title $(17.96 \%)$, scanning the text $(1.79 \%)$ and by watching videos $(0.59 \%)$ respectively. The second most preferred strategy by pre-service teachers was stimulating prior knowledge (Table 3). Pre-service teachers planned asking questions (14.38\%), explaining (8.38\%), watching videos $(1.2 \%)$, watching documentaries $(0.59 \%)$ and brainstorming $(0.59 \%)$ activities for this strategy.

Other pre-reading strategies used by pre-service teachers were: Forming questions (5.99\%), pre-teaching vocabulary formation (4.79\%), forming reading objective (3.59\%), cooperative reading $(0.59 \%)$ and teaching concepts in advance $(0.59 \%)$.

The proof chain formed with the statements of pre-service teacher A37F, who used most preferred strategy, guessing is as follows.

Statement 3: Before starting reading, I would ask my students to look at the pictures of the text and think on what the text could be about. Then, I would ask my students to share their opinions by letting as many of them as possible.

Table 4. Reading Comprehension Strategies Used For Pre-Reading

\begin{tabular}{|c|c|c|c|}
\hline Strategy & Environment & $f$ & $\%$ \\
\hline \multirow{4}{*}{ Guessing } & By Visuals & 56 & 27.54 \\
\hline & By title & 30 & 17.96 \\
\hline & By scanning the text & 3 & 1.79 \\
\hline & By watching a video & 1 & 0.59 \\
\hline \multirow{6}{*}{ Stimulation prior knowledge } & By asking questions & 24 & 14.38 \\
\hline & By explaining & 14 & 8.38 \\
\hline & By visuals & 9 & 5.39 \\
\hline & By watching video & 2 & 1.2 \\
\hline & $\begin{array}{c}\text { By watching } \\
\text { documentaries }\end{array}$ & 1 & 0.59 \\
\hline & By brainstorming & 1 & 0.59 \\
\hline Forming questions & Question-answer & 10 & 5.99 \\
\hline Pre- teaching vocabulary & Question-answer & 8 & 4.79 \\
\hline Forming reading objective & Question-answer & 6 & 3.59 \\
\hline Cooperative reading & Heterogeneous groups & 1 & 0.59 \\
\hline Teaching concepts in advance & Concept maps & 1 & 0.59 \\
\hline TOTAL & & 167 & 100 \\
\hline
\end{tabular}


Statement 5: Before reading text, I would ask them to have a look at it first. I would expect them to see some bold parts or dialogues that could provide information about the text. would ask them to re-think by combining what they thought by looking at the pictures and by scanning.

Statement 6: I would ask them if they knew the author of the text and they had read other texts by the same author before. If they had, I would remind them those texts. If they hadn't, I would remind one story they knew. Then based on that story, I would ask them to think about what kind of stories the author could write.

According to the statements provided above, that pre-service teacher planned to use pre-reading guessing strategy by visuals first, then scanning and finally stimulating the prior knowledge on the author.

Evaluation of the during-reading comprehension strategies used by pre-service classroom teachers

The findings related to the during-reading comprehension strategies used by pre-service teachers are presented in Table 5.

Table 5. Reading Comprehension Strategies Used For During-Reading

\begin{tabular}{crr}
\hline Strategy & $f$ & $\%$ \\
\hline Oral reading by an effective reader & 27 & 22.69 \\
\hline Defining vocabulary items & 26 & 21.85 \\
\hline Answering questions, forming new questions & 24 & 20.17 \\
\hline Underlining the text & 17 & 14.29 \\
\hline Providing fluent and absorbing reading & 14 & 11.76 \\
\hline Taking story map into consideration for & 6 & 5.04 \\
\hline narrative texts & 2 & 1.68 \\
\hline Note taking & 2 & 1.68 \\
\hline Using visuals for narrative texts & 1 & 0.84 \\
\hline Defining complicated points & 119 & 100 \\
\hline TOTAL
\end{tabular}

As presented in Table 5, pre-service teachers used only 9 of the 26 during-reading strategies presented in the literature and they designed 119 teaching environment for these 9 strategies. The most repeated during-reading strategy by the pre-service teachers was oral reading of the text by an effective reader (22.69\%). Additionally, other most preferred during-reading strategies by the pre-service teachers were: "Defining vocabulary items" (21.85\%), "Answering questions and forming new questions" (20.17\%), "underlining the text" (14.29\%) and providing fluent and absorbing reading" (11.76\%).

The least used during-reading strategies were: "Taking story map into consideration for narrative texts" (5.04\%), "note taking" (1.68\%), "using visuals for narrative texts" (1.68\%) and "defining complicated points" (0.84\%).

The proof chain formed with the statements of pre-service teacher H67M, who used most preferred during-reading strategy, oral reading of the text by an effective reader is as follows:

Statement 13: After students read the text silently on their own, I would read the text or ask someone who is good to read it orally.

Statement 14: I would pay attention to intonation, punctua tion, pausing when necessary.

Statement 16: If needed, I would ask several students to read the text orally again.
Evaluation of the post-reading comprehension strategies used by pre-service classroom teachers

The findings related to the post-reading comprehension strategies used by pre-service teachers are presented in Table 6.

Table 6. Reading Comprehension Strategies Used For Post-Reading

\begin{tabular}{|c|c|c|c|}
\hline Strategy & Sub-strategy & $f$ & $\%$ \\
\hline Finding the main idea & - & 54 & 30.86 \\
\hline Visualizing the text & - & 49 & 28 \\
\hline Summarizing & - & 40 & 22.86 \\
\hline $\begin{array}{c}\text { Answering text related } \\
\text { questions }\end{array}$ & - & 16 & 9.14 \\
\hline Drawing & - & 4 & 2.29 \\
\hline \multirow{3}{*}{ Synthesizing } & $\begin{array}{c}\text { Writing a } \\
\text { follow-up for the } \\
\text { story }\end{array}$ & 3 & 1.71 \\
\hline & Writing stories & 4 & 2.29 \\
\hline & Writing fables & 1 & 0.57 \\
\hline Evaluation & - & 2 & 1.14 \\
\hline $\begin{array}{l}\text { Forming charts for the } \\
\text { text }\end{array}$ & - & 1 & 0.57 \\
\hline $\begin{array}{l}\text { Comparing with the } \\
\text { guesses }\end{array}$ & - & 1 & 0.57 \\
\hline TOTAL & & 175 & 100 \\
\hline
\end{tabular}

As presented in Table 6, pre-service teachers used only 10 of the 15 post-reading strategies presented in the literature and they designed the total of 175 teaching environment for these 10 strategies. The most repeated post-reading strategy by the pre-service teachers was finding the main idea (30.86\%). Additionally, other most preferred post-reading strategies by the pre-service teachers were: "visualizing the text" (28\%), "summarizing" (22.86\%), "answering questions formed pre/post-reading" (20.57\%), "finding the main idea" (10.29\%) and "answering text related questions" (11.76\%)

The least used post-reading strategies were: "forming charts for the text" $(0.57 \%)$, and "comparing with the guesses" (0.57\%).

The proof chain formed with the statements of pre-service teacher K48M, who used most preferred post-reading strategy, finding the main ideas is as follows:

Statement 4: After reading the text, I would ask the students to find the main idea.

Statement 5: I would ask them to combine all topics and developments within the text, while they find the main idea.

Statement 6: I would ask almost every student in the class to tell the main idea they found.

Which whole-reading process comprehension strategies do pre-service classroom teachers prefer to use?

The findings related to the whole-reading process comprehension strategies used by pre-service teachers are presented in Table 7. 
Table 7. Reading Comprehension Strategies Used for Whole-Reading Process

\begin{tabular}{ccc}
\hline Strategy & $f$ & $\%$ \\
\hline Asking question/questions & 7 & 77.78 \\
\hline Note taking & 2 & 22.22 \\
\hline TOTAL & 9 & 100 \\
\hline
\end{tabular}

As presented in Table 7, pre-service teachers used only 2 of the 11 whole reading process strategies presented in the literature and they designed the total of 9 teaching environment for these 2 strategies. The most repeated whole reading process comprehension strategy by the pre-service teachers was asking question/questions (77.78\%). Additionally, the least used whole reading process strategies was: "note taking" (22.22\%).

The proof chain formed with the statements of pre-service teacher E21F, who used most preferred whole-reading process strategy, asking question/questions is as follows:

Statement 2: Before reading, I would ask what some of the key concepts that can enable students to understand the text are.

Statement 3: I would ask questions about the topic of the text. I would ask them to think about these questions as they read the text.

Statement 4: I would ask them to answer these questions after they read the text.

\section{Results and Discussion}

The present study conducted with the purpose of defining the reading comprehension strategies considered applicable in the classroom by pre-service classroom teachers and their practical designs related to these strategies; in terms of selecting text appropriate strategy, and full and correct use of the strategies in reading process (pre-reading, during-reading, post-reading, whole reading process) within the conceptual framework defined in the literature analysed reading activity plans designed by 140 pre-service classroom teachers and obtained the following findings.

Almost half of the pre-service teachers $(50.71 \%)$ developed reading comprehension strategies for whole reading process. Almost one third of the pre-service teachers (32.86\%) designed activities only for two of the reading processes. Most of these pre-service teachers preferred pre-reading and post-reading strategies in their plans. Most of the pre-service teachers, who designed for a single process preferred post-reading strategies. Accordingly, we can claim that pre-service teachers reflected post-reading strategies the most and during-reading strategies the least on their designs. These findings of the present study are partially in agreement with the findings of the similar studies in the related literature. Firstly, that designs of the pre-service teachers included all reading processes supports the findings in the literature that pre-service teachers will use these strategies frequently (Supancic, 1995; Çöğmen, 2008; Çöğmen \& Saracaoğlu, 2009; Karasakaloğlu, 2012; Ince, 2012; Taraban et al., 2004). However, the findings related to the reading processes that pre-service teachers used most strategies respectively at post-reading, pre-reading then during-reading processes differ partially from findings of the studies conducted by Yurdaışık (2007), Karatay (2007) and Topuzkanamış (2009), who reported this order as pre-reading strategies the most and post-reading strategies the least. However, this finding is in agreement with the findings of the studies conducted by Supancic (1995) and Ince (2012).
Comparison of pre-service teachers' statements related to the content of the strategies they designed to use with the conceptual framework provided in the literature for the related strategy showed that pre-service teachers could use the strategy they preferred to use in all stages of reading partially fully and correctly. This finding of the present research is agreement with the findings reported in similar studies in the related literature. Similarly, Ünal (2006), Karatay (2007) and Topuzkanamış's (2009) findings indicated that students' levels of using reading comprehension strategies were medium level.

It has been found that, pre-service teachers used almost half of strategies defined as pre-reading strategies in the literature. Among the used strategies, the most repeated ones were guessing by visuals and stimulating prior knowledge. This finding is in agreement with the literature. Supancic's (1995) research findings indicate similar pre-reading strategy use frequencies. Moreover, according to related literature, stimulating prior knowledge and guessing strategies are among the most commonly used strategies (Ince, 2012; Baydık, 2011).

According to the findings of the study, pre-service teachers used only a few of the during-reading strategies defined in the literature. Among these, most repeated strategies were oral reading of the text by an effective reader, defining vocabulary items and seeking answers to the questions. This finding can be claimed to be consistent with the study itself. That pre-service teacher preferred to use very few during-reading strategies is consistent with the finding that the strategies used reflected the very few of during-reading strategies defined in the literature. In other words, pre-service teachers used during-reading strategies less than the strategies defined for other stages of reading. Additionally, the finding that the most used during-reading strategies were seeking answer to questions and defining vocabulary items is in agreement with the findings reported by the similar studies in the literature (Ince, 2012; Supancic, 1995; Blachowicz \& Fisher, 2000).

It was found that, pre-service teachers used most of the post-reading strategies defined in the literature. The most repeated post-reading strategy by the pre-service teacher was finding the main idea strategy. This finding is also in agreement with the study itself. Pre-service designed post-reading strategies the most, and the strategy variation was accordingly the most for post-reading. This finding is also in agreement with the literature. Taraban et al. (2004) reported that analytical strategies were frequently used by pre-service teachers. Finding the main idea strategy is an analytical strategy, which indicates agreement between the findings of two studies.

The findings of the present study showed that pre-service teachers used very few of the strategies covering whole reading process. The most repeated of these was asking question/questions strategy. In other words, very few of the pre-service teachers preferred to use strategies that can be applied to whole reading process.

The following suggestions were developed in accordance with the findings reported above: (1) Pre-service classroom teachers should be made to have theoretical and practical information about the reading comprehension strategies that they can use in every stage of reading process. Pre-service teachers should be able to use different strategies; (2) Pre-service teachers should be provided with sources on the strategies that can be applied to whole reading process; (3) Further qualitative studies can be conducted to evaluate teachers' and/or pre-service teachers' use of reading comprehension strategies. 


\section{References}

Akyol, H. (1999). Hikâye Haritası Yöntemiyle Metin Öğretimi. Millî Eğitim Dergisi. 142, 55-57.

Akyol, H. (2011). Tükçe Öğretim Yöntemleri. Ankara:Pegem Akademi.

Andrew D. (1990), Language Learning: Insights for Learners, Teachers and Researchers, Newbury House Publishers, New York.

Barnett, M. A. (1988). Reading through Context: How Real and Perceived Strategy Use Affects L2 Comprehension. The Modern Language Journal, 72(2), 150-162

Baydık, B. (2011). Okuma güçlüğü olan öğrencilerin üstbilişsel okuma stratejilerini kullanımı ve öğretmenlerin okuduğunu anlama öğretim uygulamalarının incelenmesi. Eğitim ve Bilim, 36(162), 301-319.

Blachowicz, C. L. Z., \& Fisher, P. (2000). Teaching vocabulary in all classrooms. Englewood Cliffs, NJ: Prentice Hall. Cohen,

Collins, M. D., \& Cheek, E. H. (1999). Assessing \& guiding reading instruction. New York: The McGrawHill Companies, Inc.

Çöğmen, S. (2008). Eğitim fakültesi öğrencilerinin kullandıkları okuduğunu anlama stratejileri. Yayımlanmamış Yüksek Lisans Tezi, Adnan Menderes Üniversitesi Sosyal Bilimler Enstitüsü, Aydın.

Çöğmen, S., \& Saracaloğlu, A. S. (2010). Üst Bilişsel Okuma Stratejileri Ölçeği'nin Türkçeye Uyarlama Çalışmaları. Pamukkale Üniversitesi Eğitim Fakültesi Dergisi, 28(2), 91-99.

Daly, E.J. III, Chafouleas, S. Skinner, C.H. (2005). Interventions For Reading Problems. NewYork: The Guilford Press.

Duke, N., \& Pearson, P. D. (2002). Effective practices for developing reading comprehension. In A. Farstrup \& S. J. Samuels (Eds.), What research has to say about reading instruction (pp. 205-242). Newark, DE: International Reading Association.

Ekiz, D. (2009). Bilimsel Araştırma Yöntemleri. Ankara: Anı Yayıncılık

Epçaçan, C. (2009). Okuduğunu anlama stratejilerine genel bir bakış. Uluslararası Sosyal Araştırmalar Dergisi, 2(6)

Graesser, A. C., Golding, J. M., \& Long, D. L. (1991). Narrative representation and comprehension. In R. Barr M. L. Kamil, P. Mosenthal, \& R. D. Pearson (Eds.), The handbook of reading research, Vol. 2, pp. 171205. NY: Longman.

Harris, T., \& Hodges, R. (1995). The literacy dictionary (p. 207). Newark, DE: International Reading Association.

Ince, Y. (2012). Sınıf Öğretmenlerinin Türkçe Derslerinde Kullandıkları Okuduğunu Anlama Stratejileri. Yayımlanmamış Yüksek Lisans Tezi, Uşak Üniversitesi Sosyal Bilimler Enstitüsü, Uşak.

Karatay, H. (2007). Illkögretim türkçe ögretmeni adaylarının okudugunu anlama becerileri üzerine alan arastırması. Yayımlanmamıs Doktora Tezi, Gazi Üniversitesi, Egitim Bilimleri Enstitüsü, Ankara.

Karasakaloğlu, N. (2012). Sınıf Öğretmeni Adaylarının Okuduğunu Anlama Stratejileri ile Öğrenme ve Ders Çalışma Stratejileri Arasındaki İlişki. Kuram ve Uygulamada Eğitim Bilimleri. 12(3), 1921-1950.

Patton, M.Q. (1997). How to use qualitative methods in evaluation. Newbury park, CA: SAGE Publications.

Piloneita, P. (2006). Genre and Comprehension Straregies Presented In Elementary Basal Reading Programs: A Content Analysis. Unpublished Doctoral Dissertation, Coral Fables Florida, University Of Miami.

Supancic, S. A. (1995). A descriptive study of the use of reading strategies in illinois vocational classrooms. Yayımlanmamış Yüksek Lisans Tezi, Southern Illinois University, Department of Plant, Soil and Agriculture Systems, Illinois.

Susar Kırmızı, F. (2006). illköğretim 4. sinif türkçe öğretiminde çoklu zeka kuramina dayali işbirlikli öğrenme yönteminin erişi, tutumlar, ögrenme stratejileri ve çoklu zeka alanlari üzerindeki etkileri. Yayımlanmamış doktora tezi, Dokuz Eylül Üniversitesi, Eğitim Bilimleri Enstitüsü, İzmir.

Taraban, R., Kerr, M. \& Rynearson, K. (2004). Analytic and Pragmatic Factors in College Students' Metacognitive Reading Strategies. Reading Psychology, 25(2), 67-81.

Topuzkanamış, E. ve Maltepe, S. (2010). Öğretmen AdayIarının Okuduğunu Anlama ve Okuma Stratejilerini Kullanma Düzeyleri. TÜBAR-XXVII-655-677.

Ünal, E. (2006). Ilkögretim ögrencilerinin elestirel okuma becerileri ile okudugunu anlama ve okumaya iliskin tutumları arasındaki iliski. Yayımlanmamıs Yüksek Lisans Tezi, Eskisehir Osmangazi Üniversitesi, Sosyal Bilimler Enstitüsü, Eskisehir.

Yıldırım, A., \& Şimşek, H. (2005) Sosyal Bilimlerde Nitel Aratırma Yöntemleri. Ankara: Seçkin yayıncılık.

Yıldırım, A., \& Şimşek, H. (2008). Sosyal Bilimlerde Nitel Araştırma Yöntemleri. Ankara: Seçkin Yayıncılık.

Yin, R.K. (2003). Case Study Research: Design and Methods. Sage. Thousand Oaks, California. 
Appendix

Reading Activity Form

Dear pre-service teacher, design a reading activity for 3rd or 4th graders for the narrative text "Turtle-The Pottery Master" you are provided with. Use the table below. You can use one, several or all lesson parts listed below.

\begin{tabular}{|c|c|l|l|l|}
\hline Lesson Part & $\begin{array}{c}\text { Teaching-Learning } \\
\text { Activity and the Reason } \\
\text { for Using it }\end{array}$ & Role of the Teacher & Role of the Students & Teaching Tools \\
\hline Introduction & & & & \\
\hline Pre-reading & & & & \\
\hline During-reading & & & & \\
\hline Post-reading & & & & \\
\hline Assessment & & & & \\
\hline
\end{tabular}

Other cases you would like to add:

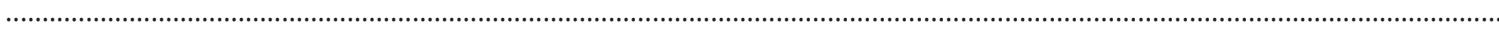

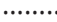

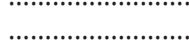

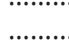

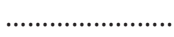

.........

.........

.....................

....... 